\title{
The Effect of Urban Services Development on Regional Economic Growth in China
}

\author{
- Based on Provincial Panel Data Analysis
}

\author{
Yuan Gao ${ }^{1}$, ABDUL Razak bin Chik ${ }^{2}$ \\ School of Economics, Finance \&Banking, COB, University Utara Malaysia, 06010 Sintok, Kedah, Malaysia \\ College of Economics, HeBei University, 071000, BaoDing, , HeBei, China \\ Email: michelle811@126.com, arc@uum.edu.my
}

Received 2012

\begin{abstract}
The indicator of urban success is the success of its urban services. Although much research on services have been made, there is major gap with regard to the regional services, especially on urban services within a country. As the Chinese government intends to accelerate the development of urban services and regional economy in the present Twelfth Five-Year Plan 2011-2015, the main purpose of this paper is to investigate the effect of urban services development on regional growth. By using panel data of 30 provinces in China from 2001-2011 and through GLS estimation of the random effect panel data model, it is found that the growth of urban services performed rather well in promoting regional economic growth of all of the three regions in China. But the promoting role of urban services on regional economic growth in this three regions were different among which, the role of urban services in eastern region were strongest , followed by central region and weakest in Western region.
\end{abstract}

Keywords: Urban Services; Regional Growth; Panel Data Analysis

\section{Introduction}

Since reform and opening up, China has made remarkable economic achievements. In the growing process, its economic structure has also undergone a transformation, and its industrial structure has been gradually optimized and deepened. One important manifestation is the status of services in China's economy has been greatly enhanced that their role in promoting economic development has been growing(Cheng,2003).Urban are the main carrier for services' development (Ji,2004.In 2009, 71\% of value added services in China was created by 285 cities at prefecture level. (Source of data: China statistical Yearbook, 2010). Urban services are playing an increasingly important role in the sustained and rapid growth of Chinese economy, but problems of inadequate total output, inferior internal structure , apparent regional disparities, have become major resistance in urban services' growth. Especially, the expanding regional gap in services is bound to affect its sustainable development as well as enlarge the imbalance in regional economies.

Therefore, the main purpose of this study is to investigate the effect of urban services growth on regional growth in China.

\section{Specifications of Panel Data Model}

\subsection{The Data}

This paper selected prefecture-level cities of 30 provinces of China, excepting Tibet ,Hong Kong, Macao and Taiwan, municipalities. The main method of data collection is the analysis of documents of official statistics. Therefore, the main sources of data are secondary data and the data source is from corresponding year of China Statistical Yearbook and China Urban Yearbook. Foreign direct investment data will be from the corresponding year of the "China Foreign Economic and Trade Yearbook".

\subsection{Variables}

In this study, the panel data model will be used. In order to measure the regional effect, the 30 provinces of China will be divided into eastern, central and western regions. Economic growth theory focus on the role of various factors in the process of long-term economic growth. The structural school hold that economic growth and industrial structural change are strongly interrelated. From the classical economic growth theory, the neoclassical economic growth theory to the new economic growth theory, all regard physical capital as one of the important factors promoting economic growth. 
Since the New Institutional Economics, institutional factors are begun to be regarded as endogenous variables for economic growth rather than exogenous variables. Economic openness level is an important institutional factors of economic growth (Barro, 1996). Therefore, based on the above analysis on factors influencing regional growth as well as in combination of New Growth Theory and the New Geographical Economics, the model here will introduce regional urban services growth level(RURBS), regional industrial growth level(RIND), regional openness level(RFDI), regional physical capital investment level,(RINV) and regional urban services concentration level (RUSLQ), as independent variables for analysis.

The basic unrestricted panel data model is

$\operatorname{lnRGDP}{ }_{\mathrm{it}}=\mathrm{a}_{\mathrm{it}}+\beta_{1 \mathrm{it}} \operatorname{lnRURBS_{\mathrm {it}}}++\beta_{2 \mathrm{it}} \operatorname{lnRIND} \mathrm{it}_{\mathrm{it}}+\beta_{3 \mathrm{it}} \ln +$

$\beta_{5 \mathrm{it}} \mathrm{RUSLQ}_{\mathrm{it}+} \xi_{\text {it }}$

$\mathrm{i}=1,2 \ldots .30 ; \mathrm{t}=1,2 \ldots .10$

$\alpha_{\text {it }}$ : intercept coefficients that vary across individual(city) $\mathrm{i}$ and time $\mathrm{t}$

$\beta_{\text {kit }}$ : ( $\beta$ 1it, $\beta 2$ it, $\quad \beta 6$ it) 55 kectors of slope par ameters that vary across individual (city) $\mathrm{i}$ and time $\mathrm{t}$

$\xi_{\text {it }}:$ the error term.

i: the number of individual members,

$\mathrm{t}$ : the number of time .

$\mathrm{RGDP} i=$ the regional economic growth level, which is the regional GDP of region i

RURBSi $=$ regional urban services growth level, which is the urban services output value of region $\mathrm{i}$

RINDi=regional secondary industrial growth level, which is the secondary industry's output value of region $i$

$\mathrm{RFDIi}=$ regional openness level, which is the value of FDI in region $\mathrm{i}$

$\mathrm{RINVi}=$ the regional physical capital, which is the fixed capital investment in region $\mathrm{i}$

RUSLQi =regional urban services' concentration, which is the regional urban services' location quotient

As for the independent variable of FDI, it will firstly be converted to the value of the Renminbi using the average exchange rate of corresponding year. As for the variables of RGDP, RURBS, RIND, RFDI ,RINV, they were converted into the value calculated by the constant 1978 consumer price index. Then take the natural logarithm of those above five variables to eliminate heteroscedasticity. It is assumed that parameters are constant over time $t$, but can vary across individuals. Thus, the procedures to estimate the model based on the panel data approach may be summed up in terms of the following:
1) panel unit root test

2) panel cointegration test

3) panel data estimation

a) The Estimate of Pooled OLS Regression Model

b) The Estimate of Fixed Effect Model

c) The Estimate of Random Effect Model

\section{Results of Panel Data Analysis}

\subsection{Results of Panel Unit Root Test}

Panel data is generally heterogeneous and panel unit root tests should take this heterogeneity into account. If unit root is detected in the data, the problem of spurious regression occurs in the panel data analysis as well. Therefore, the establishment of the panel unit root tests for all the series used in this study is required. In order to achieve this objective, four panel unit root tests, namely the LLC test, the IPS test, the ADF-Fisher and PP-Fisher tests were used. Table1,2,3 present the results of panel unit root tests for all variables of the eastern, central and western regions in level and first differences respectively.

Table 1. Panel Unit Root Test of Eastern Region

\begin{tabular}{|c|c|c|c|c|}
\hline Variables & LLC & IPS & ADF-Fisher & PP-Fisher \\
\hline $\ln R G D P$ & $\begin{array}{c}-3.41156^{* * *} * \\
(0.0003)\end{array}$ & $\begin{array}{l}1.49109 \\
(0.9307)\end{array}$ & $\begin{array}{l}16.3035 \\
(0.8005)\end{array}$ & $\begin{array}{c}18.0488 \\
(0.7031)\end{array}$ \\
\hline$\Delta$ LnRGDP & $\begin{array}{c}-7.38111 * * * \\
\quad(0.0000)\end{array}$ & $\begin{array}{c}-3.32088^{* * *} * \\
(0.0000)\end{array}$ & $\begin{array}{c}55.0617 * * * \\
(0.0000)\end{array}$ & $\begin{array}{c}92.0948 * * * \\
(0.0000)\end{array}$ \\
\hline LnURBS & $\begin{array}{l}2.33095 \\
(0.9901)\end{array}$ & $\begin{array}{l}4.60432 \\
(1.0000)\end{array}$ & $\begin{array}{l}2.98307 \\
(1.0000)\end{array}$ & $\begin{array}{l}6.25405 \\
(0.9996)\end{array}$ \\
\hline$\Delta \mathrm{LnURBS}$ & $\begin{array}{c}-7.65319 * * * \\
(0.0000)\end{array}$ & $\begin{array}{c}-4.07128 * * * \\
(0.0000)\end{array}$ & $\begin{array}{c}62.2028 * * * \\
(0.0000)\end{array}$ & $\begin{array}{c}93.4541 * * * \\
(0.0000)\end{array}$ \\
\hline LnRIND & $\begin{array}{c}-5.28922 * * * \\
(0.0000)\end{array}$ & $\begin{array}{r}-0.03884 \\
(0.5155)\end{array}$ & $\begin{array}{c}22.9356 \\
(0.4054)\end{array}$ & $\begin{array}{l}47.5891 \\
(0.112)\end{array}$ \\
\hline$\Delta$ LnRIND & $\begin{array}{c}-6.43702 * * * \\
\quad(0.0000)\end{array}$ & $\begin{array}{c}-2.91072 * * * \\
(0.0018)\end{array}$ & $\begin{array}{c}49.3245 * * * \\
(0.0007)\end{array}$ & $\begin{array}{c}71.9833 * * * \\
(0.0000)\end{array}$ \\
\hline LnRFDI & $\begin{array}{c}-6.55210 * * * \\
(0.0000)\end{array}$ & $\begin{array}{l}-2.04374 \\
(0.1205)\end{array}$ & $\begin{array}{c}40.7588 \\
(0.1088)\end{array}$ & $\begin{array}{c}48.0670 \\
(0.1011)\end{array}$ \\
\hline$\Delta \mathrm{LnRFDI}$ & $\begin{array}{c}-35.9245 * * * \\
(0.0000)\end{array}$ & $\begin{array}{c}-12.5731^{* * *} \\
(0.0000)\end{array}$ & $\begin{array}{c}77.4337 * * * \\
(0.0000)\end{array}$ & $\begin{array}{c}63.6200 * * * \\
(0.0000)\end{array}$ \\
\hline LnRINV & $\begin{array}{c}-6.65391 * * * \\
(0.0000)\end{array}$ & $\begin{array}{r}-1.63444 \\
(0.2971)\end{array}$ & $\begin{array}{l}45.6700 \\
(0.0022)\end{array}$ & $\begin{array}{c}40.2504 \\
(0.101)\end{array}$ \\
\hline$\Delta \mathrm{LnRINV}$ & $\begin{array}{c}-3.05303 * * * \\
(0.0011)\end{array}$ & $\begin{array}{c}-2.43119 * * * \\
(0.0075)\end{array}$ & $\begin{array}{c}42.9095 * * * \\
(0.0048)\end{array}$ & $\begin{array}{c}54.7290 * * * \\
(0.0001)\end{array}$ \\
\hline RUSLQ & $\begin{array}{l}-0.23109 \\
(0.4086)\end{array}$ & $\begin{array}{c}1.39201 \\
(0.9180)\end{array}$ & $\begin{array}{c}13.3331 \\
(0.9235)\end{array}$ & $\begin{array}{l}7.89520 \\
(0.9974)\end{array}$ \\
\hline$\triangle$ RUSLQ & $\begin{array}{c}-8.41031 * * * \\
(0.0000)\end{array}$ & $\begin{array}{c}-2.74520 * * * \\
(0.0030)\end{array}$ & $\begin{array}{c}45.7461 * * * \\
(0.0021)\end{array}$ & $\begin{array}{c}36.7195 * * \\
(0.0254)\end{array}$ \\
\hline
\end{tabular}


Table 2. Panel Unit Root Test of Central Region

\begin{tabular}{|c|c|c|c|c|}
\hline VariableS & LLC & IPS & ADF-Fisher & PP-Fisher \\
\hline $\operatorname{lnRGDP}$ & $\begin{array}{l}0.11412 \\
(0.5454) \\
\end{array}$ & $\begin{array}{l}4.57127 \\
(1.0000)\end{array}$ & $\begin{array}{l}12.2803 \\
(0.8324) \\
\end{array}$ & $\begin{array}{c}3.82243 \\
(0.9998)\end{array}$ \\
\hline$\triangle \mathrm{LnRGDP}$ & $\begin{array}{c}-6.44980^{* * * *} \\
(0.0000)\end{array}$ & $\begin{array}{c}-2.67387 * * * \\
(0.0037)\end{array}$ & $\begin{array}{c}40.2066^{* * * *} \\
(0.0020)\end{array}$ & $\begin{array}{c}46.0917^{* * *} * \\
(0.0003)\end{array}$ \\
\hline LnURBS & $\begin{array}{c}0.29886 \\
(0.6175)\end{array}$ & $\begin{array}{l}3.44430 \\
(0.9997)\end{array}$ & $\begin{array}{l}7.28797 \\
(0.9875)\end{array}$ & $\begin{array}{l}16.1943 \\
(0.5790)\end{array}$ \\
\hline$\triangle$ LnURBS & $\begin{array}{c}-9.78617^{* * *} * \\
(0.0000)\end{array}$ & $\begin{array}{c}-4.78816^{* * *} \\
(0.0000)\end{array}$ & $\begin{array}{c}58.7528^{* * *} * \\
(0.0000)\end{array}$ & $\begin{array}{c}71.1539 * * * \\
(0.0000)\end{array}$ \\
\hline LnRIND & $\begin{array}{c}-2.18758^{* *} \\
(0.0144) \\
\end{array}$ & $\begin{array}{l}2.63085 \\
(0.9957) \\
\end{array}$ & $\begin{array}{c}20.5155 \\
(0.3046) \\
\end{array}$ & $\begin{array}{l}5.99318 \\
(0.9962) \\
\end{array}$ \\
\hline$\triangle$ LnRIND & $\begin{array}{c}-11.0591^{* * *} * \\
(0.0000)\end{array}$ & $\begin{array}{c}-4.75058^{* * *} * \\
(0.0001)\end{array}$ & $\begin{array}{c}58.9425^{* * *} * \\
(0.0000)\end{array}$ & $\begin{array}{c}63.3457^{* * * *} \\
(0.0000)\end{array}$ \\
\hline LnRFDI & $\begin{array}{c}-7.17571^{* * *} * \\
(0.0000)\end{array}$ & $\begin{array}{c}-2.63604 \\
(0.4002)\end{array}$ & $\begin{array}{l}42.0424 \\
(0.1001)\end{array}$ & $\begin{array}{l}54.2346 \\
(0.4996)\end{array}$ \\
\hline$\Delta$ LnRFDI & $\begin{array}{c}-6.32490^{* * * *} \\
(0.0000)\end{array}$ & $\begin{array}{c}-3.09648^{* * *} \\
(0.0010)\end{array}$ & $\begin{array}{c}44.4724^{* * *} \\
(0.0005)\end{array}$ & $\begin{array}{c}53.3206^{* * * *} \\
(0.0000)\end{array}$ \\
\hline LnRINV & $\begin{array}{c}-4.72129 * * * \\
(0.0000)\end{array}$ & $\begin{array}{l}1.12683 \\
(0.8701)\end{array}$ & $\begin{array}{l}27.3854 \\
(0.7720)\end{array}$ & $\begin{array}{l}24.0519 \\
(0.1533)\end{array}$ \\
\hline$\Delta \operatorname{LnRINV}$ & $\begin{array}{c}-5.15385^{* * *} * \\
(0.0000)\end{array}$ & $\begin{array}{c}-2.26904^{* * *} \\
(0.0016)\end{array}$ & $\begin{array}{c}1.2806^{* * *} \\
(0.0014)\end{array}$ & $\begin{array}{c}42.0216^{* * *} * \\
(0.0011)\end{array}$ \\
\hline RUSLQ & $\begin{array}{c}-2.92497 * * * \\
(0.0017)\end{array}$ & $\begin{array}{l}0.47619 \\
(0.6830) \\
\end{array}$ & $\begin{array}{c}15.2035 \\
(0.6479) \\
\end{array}$ & $\begin{array}{l}8.83453 \\
(0.9635) \\
\end{array}$ \\
\hline$\triangle$ RUSLQ & $\begin{array}{c}-7.72440 * * * \\
(0.0000)\end{array}$ & $\begin{array}{c}-2.70246 * * * \\
(0.0034)\end{array}$ & $\begin{array}{c}42.4281 * * * \\
(0.0010)\end{array}$ & $\begin{array}{c}41.0687^{* * *} \\
(0.0015)\end{array}$ \\
\hline
\end{tabular}

Table 3 Panel Unit Root Test of Western Region

\begin{tabular}{|c|c|c|c|c|}
\hline Variables & LLC & IPS & ADF-Fisher & PP-Fisher \\
\hline lnRGDP & $\begin{array}{l}0.72723 \\
(0.7665) \\
\end{array}$ & $\begin{array}{l}3.34722 \\
(0.9996) \\
\end{array}$ & $\begin{array}{l}7.92517 \\
(0.9924) \\
\end{array}$ & $\begin{array}{l}20.3176 \\
(0.4382) \\
\end{array}$ \\
\hline$\Delta$ LnRGDP & $\begin{array}{c}-10.8697 * * * \\
(0.0000)\end{array}$ & $\begin{array}{c}-5.47508^{* * *} \\
(0.0000)\end{array}$ & $\begin{array}{c}72.0451 * * * \\
(0.0000)\end{array}$ & $\begin{array}{c}92.4649 * * * \\
(0.0000)\end{array}$ \\
\hline LnURBS & $\begin{array}{l}1.54311 \\
(0.9386) \\
\end{array}$ & $\begin{array}{l}3.25452 \\
(0.9994) \\
\end{array}$ & $\begin{array}{l}6.15265 \\
(0.9987) \\
\end{array}$ & $\begin{array}{r}11.9402 \\
(0.9181) \\
\end{array}$ \\
\hline$\triangle$ LnURBS & $\begin{array}{c}-12.9241 * * * \\
(0.0000)\end{array}$ & $\begin{array}{c}-7.10347 * * * \\
(0.0000)\end{array}$ & $\begin{array}{c}85.473 * * * 9 \\
(0.0000)\end{array}$ & $\begin{array}{c}105.007^{* * *} * \\
(0.0000)\end{array}$ \\
\hline LnRIND & $\begin{array}{l}-0.32214 \\
(0.3737) \\
\end{array}$ & $\begin{array}{l}3.47264 \\
(0.9997)\end{array}$ & $\begin{array}{c}7.98654 \\
(0.9920) \\
\end{array}$ & $\begin{array}{l}22.5393 \\
(0.3120) \\
\end{array}$ \\
\hline$\Delta$ LnRIND & $\begin{array}{c}-5.90752^{* * *} \\
(0.0000)\end{array}$ & $\begin{array}{c}-2.75070^{* * *} \\
(0.0030)\end{array}$ & $\begin{array}{c}43.1060^{* * * *} \\
(0.0020)\end{array}$ & $\begin{array}{c}68.8049^{* * *} * \\
(0.0000)\end{array}$ \\
\hline LnRFDI & $\begin{array}{l}-0.01347 \\
(0.4946) \\
\end{array}$ & $\begin{array}{l}1.35412 \\
(0.9122) \\
\end{array}$ & $\begin{array}{l}12.0042 \\
(0.9159) \\
\end{array}$ & $\begin{array}{l}12.4537 \\
(0.8996) \\
\end{array}$ \\
\hline$\triangle$ LnRFDI & $\begin{array}{c}-6.57424 * * * \\
(0.0000)\end{array}$ & $\begin{array}{c}-2.53827 * * * \\
(0.0056)\end{array}$ & $\begin{array}{c}2.2323 * * * \\
(0.0026) \\
\end{array}$ & $\begin{array}{c}49.5927 * * * \\
(0.0003)\end{array}$ \\
\hline LnRINV & $\begin{array}{l}2.08538 \\
(0.9815) \\
\end{array}$ & $\begin{array}{l}4.87196 \\
(1.0000)\end{array}$ & $\begin{array}{l}3.33630 \\
(1.0000)\end{array}$ & $\begin{array}{l}4.14997 \\
(0.9999)\end{array}$ \\
\hline$\triangle \mathrm{LnRINV}$ & $\begin{array}{c}-17.2966^{* * *} \\
(0.0000) \\
\end{array}$ & $\begin{array}{c}-6.55238^{* * *} * \\
(0.0000) \\
\end{array}$ & $\begin{array}{c}78.1532 * * * \\
(0.0000) \\
\end{array}$ & $\begin{array}{c}73.2743^{* * *} \\
(0.0000) \\
\end{array}$ \\
\hline RUSLQ & $\begin{array}{l}0.62422 \\
(0.7338)\end{array}$ & $\begin{array}{l}2.20535 \\
(0.9863)\end{array}$ & $\begin{array}{l}9.84979 \\
(0.9708)\end{array}$ & $\begin{array}{l}11.8704 \\
(0.9205)\end{array}$ \\
\hline$\triangle$ RUSLQ & $\begin{array}{c}-5.94630 * * * \\
(0.0000)\end{array}$ & $\begin{array}{c}-2.41096^{* * *} \\
(0.0080)\end{array}$ & $\begin{array}{c}40.1865^{* * *} * \\
(0.0047)\end{array}$ & $\begin{array}{c}4.5364 * * * \\
(0.0013)\end{array}$ \\
\hline
\end{tabular}

Note : 1. represents a first difference and those in brackets are $P$ values. 2 . The lag length chosen of each variable is based on the SIC which is automatically determined by Eviews 6.0 .3. ***,**,* represent reject the null hypothesis of existing panel unit root at 1\%, 5\%, 10\% significance level respectively,

From Table 1,2 and 3 the panel unit root tests results in level indicated the null hypothesis of non-stationary cannot be rejected at 1,5 and 10 percent levels of significance for all the series in the eastern, central and western regions. However, for the series in their first difference, the results of the panel unit root test of the three regions showed that the probability values were less than 0.10 for all series, which suggests the panel non-stationarity of the null hypothesis at 1,5 , and 10 percent levels of significance can be rejected. This indicates that all the data of the three regions were stationary in their first-difference and not in level.

\subsection{Results of Panel Cointegration Tests}

In the previous section, the results confirmed that all series of the three regions were integrated of the same order of I(1) for the panel unit root tests. This allows for testing of any possible long-run relationships among the series in the equation. To achieve this, the Panel Cointegration Tests are conducted.The Pedroni panel cointegration test results of the eastern, western and central region are summarized in Table4.

Table 4 Pedroni Panel Cointegration Test Results

\begin{tabular}{l|l|l|l}
\multicolumn{1}{c}{ Table 4 Pedroni Panel Cointegration Test } & \multicolumn{1}{c}{ Results } \\
\hline \multirow{2}{*}{$\begin{array}{l}\text { Pedroni } \\
\text { test }\end{array}$} & \multicolumn{1}{|c|}{ East } & \multicolumn{1}{c}{ Central } & \multicolumn{1}{c}{ West } \\
\cline { 2 - 4 } & Statistics \& & Statistics\& & Statistics \& \\
Prob & Prob & -1.458469 \\
Panel & -2.338948 & -1.862723 & $(0.9276)$ \\
V-Statistic & $(0.9903)$ & $(0.9687)$ & 3.279000 \\
Panel & 3.174810 & 2.657220 & $(0.9995)$ \\
rho-Statistic & $(0.9993)$ & $(0.9961)$ & $-2.000373 * *$ \\
\hline Panel & $-6.434645 * * *$ & $-3.318277 * * *$ & $(0.0227)$ \\
PP-Statistic & $(0.0000)$ & $(0.0005)$ & $-1.283375 * * *$ \\
\hline Panel & $-3.629904 * * *$ & $-2.784061 * * *$ & $(0.0097)$ \\
ADF-Statistic & $(0.0001)$ & $(0.0027)$ & 4.380933 \\
\hline Group & 4.454367 & 4.255042 & $(1.0000)$ \\
rho-Statistic & $(1.0000)$ & $(1.0000)$ & $-7.253257 * * *$ \\
\hline Group & $-12.20305 * * *$ & $-7.662945 * * *$ & $(0.0000)$ \\
PP-Statistic & $(0.0000)$ & $(0.0000)$ & $-5.71706 * * *$ \\
\hline Group & $-5.288004 * * *$ & $-2.687720 * * *$ & $(0.0000)$ \\
ADF-Statistic & $(0.0000)$ & $(0.0036)$ & \\
\hline
\end{tabular}

Note : 1. The numbers in brackets are P values. $2 . * * *, * *, *$ represen reject the null hypothesis of non cointegration relationship at 1\%, 5\%, $10 \%$ significance level respectively.

As can be seen from table 4 , all the statistics of panel PP, Panel ADF, Group PP and Group ADF of the three regions rejected the null hypothesis that there is no cointegration relationship at the $1 \%$ or $5 \%$ level of significance. While, the Panel v, Panel rho and Group rho statistics cannot reject the null hypothesis. According to Pedroni (1999\&2004), in a small sample analysis, that is, for such $\mathrm{T}<20$ short time analysis, the Panel ADF and Group ADF test results are more effective than the Panel $\mathrm{v}$, Panel rho and Group rho tests. When the test results appear inconsistent, it should follow the results of Panel ADF and Group ADF tests. Considering the sample period is only 10 years in this study, that is a small sample, the study are subject to the results of Panel ADF and Group ADF tests, through which the co integration relationship between variables can be judged.

The above test showed there exists cointegration relationship between variables, the next step is to estimate the long-run equilibrium equation (co integration equation) of the panel data model.

\subsection{The Estimation of Panel Data Model}

\subsubsection{F-Test}

To choose between pooled regression and fixed effects as a correct model,the F-test is employed. From the F 
-test statistics in Table 5 , we can see the computed values of eastern, central and western region are $81.957618,13.916878$ and 40.214670 respectively and all of their corresponding $p$-value are less than 0.1 percent, therefore we can reject the pooled least squares formulation in favor of the fixed effect model.

\begin{tabular}{c|c|c|c}
\multicolumn{2}{c}{ Table 5. Results of F-Test } & ( Pooled Versus & Fixed ) \\
\hline \multirow{2}{*}{$\begin{array}{r}\text { Cross-section } \\
\text { F -Statistic }\end{array}$} & East & Central & West \\
\cline { 2 - 4 } & $81.957618^{* * *}$ & $13.916878^{* * *}$ & $40.214670^{* * *}$ \\
\hline d. f. & $(10,94)$ & $(8,76)$ & $(9,85)$ \\
\hline Prob & 0.0000 & 0.0000 & 0.0000 \\
\hline
\end{tabular}

\subsubsection{Hausman Test}

To choose between fixed and random effects as a correct model in panel data estimation, the Hausman test is employed. The Hausman test is a test of the null hypothesis that the random effect is indeed random. If they are random, then they should not be correlated with any of other regressors. If they are correlated with others regressors, then this study should use the fixed effect estimator to obtain consistent parameter estimates of the slopes. The Hausman test results as presented in Table 6

Table 6. Hausman Test (Fixed Versus Random)

\begin{tabular}{c|c|c|c}
\hline $\begin{array}{c}\text { Cross-section } \\
\text { random }\end{array}$ & East & Central & West \\
\hline Chi-Sq.statistic & 0.000000 & 0.000000 & 0.000000 \\
\hline Chi-Sq. d. f. & 5 & 5 & 5 \\
\hline Prob & 1.0000 & 1.0000 & 1.0000 \\
\hline
\end{tabular}

The results shows that all the $p$-values of the three regions are 1 percent. This means that the null hypothesis which states that the random effect as a correct model can not be rejected, therefore the random effect model is the correct model. Thus, the results lead us to conclude that the random effect estimator is the most robust among the panel data estimates.

\subsubsection{The Estimation Results of Random Effect}

In the random effect model, the individual differences are thought to represent random variation about some average intercept for the individual in the sample. The results are reported in Table 7

Table7 The Estimation Results of Random Effect

\begin{tabular}{l|l|l|l}
\hline \multirow{2}{*}{ Variables } & Eastern & \multicolumn{1}{|c|}{ Central } & Western \\
\cline { 2 - 4 } & Coefficient & Coefficient & Coefficient \\
\hline C & $--3.843547^{* * *}$ & $-3.704251^{* * *}$ & $-3.712866^{* * *}$ \\
& $(-30.91265)$ & $(-11.26658)$ & $(-11.70397)$ \\
\hline InRURBS & $0.550115^{* * *}$ & $0.533654^{* * *}$ & $0.491060^{* * *}$ \\
& $(36.35336)$ & $(20.98316)$ & $(20.47462)$ \\
\hline InRIND & $0.459546^{* *}$ & $0.471688^{* * *}$ & $0.494801^{* * *}$ \\
\hline
\end{tabular}

\begin{tabular}{l|c|l|l}
\hline & $(29.96021)$ & $(14.61356)$ & $(19.42823)$ \\
\hline InRFDI & $-0.015329^{*}$ & -0.0001792 & $0.023328^{* * *}$ \\
& $(-1.686862)$ & $(-0.199689)$ & $(3.796136)$ \\
\hline InRINV & 0.000927 & -0.008495 & -0.002165 \\
& $(0.124881)$ & $(-0.648416)$ & $(-0.119606)$ \\
\hline RUSLQ & -0.016209 & 0.003010 & 0.133120 \\
& $(-0.425587)$ & $(0.057286)$ & $(1.483770)$ \\
\hline $\mathrm{R}^{\wedge}$ & 0.997805 & 0.996593 & 0.995361 \\
\hline D.W. & 0.768618 & 0.609147 & 0.797203 \\
\hline
\end{tabular}

Note : 1. Numbers in brackets are $t$ values. $2 . * * *, * *, *$ represent the $t$-values are statistically significant at 1\%, 5\%, 10\% level respectively

In the random effect estimation of the eastern region, the coefficients of InRURBS, InRIND have a positive coefficient and statistically significant at $1 \%$ level. Meanwhile, the independent variable of lnRFDI showed statistically significant with a negative sign. And the other two independent variables, InRINV, RUSLQ did not pass the t-test, which means they were not statistically significant in the random effect estimation.

In the random effect estimation of the central region, the independent variables of $\operatorname{lnRURBS}$, InRIND have a positive coefficients and statistically significant at 0.1 percent level. But all the other 3 independent variables did not pass the t-test, which means they were not statistically significant in the random effect estimation. In the random effect estimation of the western region, the independent variables of lnRURBS, InRIND and lnRFDI have a positive coefficient and statistically significant at 0.1 percent level. While, the other two independent variables did not pass the t-test, which means they were not statistically significant in the random effect estimation. The random effect estimation also fitted well by the value of. Adjusted- $R^{2}$ which are basically the same as results in the pooled least squares and fixed effect estimation.

\subsubsection{Serial Correlation and the GLS Estimation}

Based on the Durbin-Watson table, it has been found that in this study the lower limit $\mathrm{d}_{\mathrm{L}}$ is 0.94 and the upper limit $d_{U}$ is 1.51 at the 1 percent level of significance Therefore, under the null hypothesis that serial autocorrelation do not exist in the disturbance ui, the zone for Durbin-Watson d statistic to accept this null hypothesis is $(1.51,2.49)$. while as presented in Table 5.4.3.a the Durbin-Watson statistics are 0.768618, 0.609147and 0.797203 for the eastern, central and western region respectively meaning that we reject the null hypothesis which stated that there is no autocorrelation. Hence, it gives strong evidence that there is positive serial correlation in the residuals for the three regions in the study. The procedure correcting for serial autocorrelation uses the OLS residuals to calculate $\rho$. As cited from Gujarati and Porter (2009), one advantage of this method is that it can be used to estimate not only an AR(1) scheme, but also higher order autoregressive schemes, such as AR(2). 
The transformed equation is a form of generalized least squares estimator. Table 8 presents the results of the transformation regression for models in this study.

Table 8. The Results of GLS Estimation.

\begin{tabular}{|c|c|c|c|}
\hline \multirow{2}{*}{ Variables } & Eastern & Central & Western \\
\hline & Coefficient & Coefficient & Coefficient \\
\hline $\mathbf{C}$ & $\begin{array}{c}0.001328 \\
(0.409737)\end{array}$ & $\begin{array}{l}0.010270 * \\
(1.708042)\end{array}$ & $\begin{array}{c}0.027558 * * * \\
(2.876944)\end{array}$ \\
\hline LnRURBS $^{*}$ & $\begin{array}{c}0.509783 * * * \\
(36.73994)\end{array}$ & $\begin{array}{c}0.483780 * * * \\
(27.67434)\end{array}$ & $\begin{array}{c}0.369740 * * * \\
(13.32653)\end{array}$ \\
\hline LnRIND* & $\begin{array}{c}0.486107 * * * \\
(33.17517) \\
\end{array}$ & $\begin{array}{c}0.482190 * * * \\
(23.63773)\end{array}$ & $\begin{array}{c}0.501245 * * * \\
(15.32915)\end{array}$ \\
\hline LnRFDI $^{*}$ & $\begin{array}{c}0.000407 \\
(0.054868)\end{array}$ & $\begin{array}{c}0.006741 \\
(0.569864)\end{array}$ & $\begin{array}{c}-0.003148 \\
(-0.444209)\end{array}$ \\
\hline LnRINV* & $\begin{array}{c}-0.005606 \\
(-1.315687)\end{array}$ & $\begin{array}{c}-0.040382 * * \\
(-2.313184)\end{array}$ & $\begin{array}{c}-0.055255 * * * \\
(-2.884353)\end{array}$ \\
\hline RUSLQ* & $\begin{array}{r}0.024050 \\
(0.529949) \\
\end{array}$ & $\begin{array}{c}-0.072747 \\
(-1.353664)\end{array}$ & $\begin{array}{c}-0.156968 \\
(-1.195610) \\
\end{array}$ \\
\hline $\mathrm{R}^{\prime 2}$ & 0.978742 & 0.951707 & 0.880199 \\
\hline F-Statistic & $903.3878 * * *$ & $316.3097 * * *$ & $131.7792 * * *$ \\
\hline D.W. & 2.465143 & 2.358193 & 2.315435 \\
\hline
\end{tabular}

Note : 1. Numbers in brackets are $\mathrm{t}$ values.2. .***,**,* represent the t-values are significant at $1 \%, 5 \%, 10 \%$ level respectively

From the table 8 , we can see in the GLS estimation of the random effect model of eastern region, the coefficients of $\operatorname{lnRURBS} *$, lnRIND* have a positive coefficient and statistically significant at $1 \%$ and $10 \%$ levels. Meanwhile, the other independent variables, lnRFDI*, InRINV*, RUSLQ* did not pass the t-test, which means they were not statistically significant in the GLS estimation. The GLS estimation is reasonably fit as indicated by the Adjusted- $\mathrm{R}^{2}$ of 0.978724 , means that about 98 percent of the variation in explanatory variable can be explained by the variation in the dependent variables. As for the D.W. statistic, it has been greatly increased from 0.768618 to 2.465143 which is in the zone of non autocorrelation problem.

In the GLS estimation of the central region, the independent variables of $\ln R U R B S *, \ln R I N D *$ have a positive coefficients and statistically significant at $1 \%$ level. But the independent variable of 1 RINV* showed statistically significant with a negative sign. The other two independent variables LnRFDI*, USLQ*did not pass the t-test, which means they were not statistically significant in the GLS estimation. The GLS estimation is reasonably fit as indicated by the Adjusted- $\mathrm{R}^{2}$ of 0.951707 , meaning that about 95 percent of the variation in regional GDP of central region can be explained by the variation in the dependent variables. As for the D.W. statistic, it has been greatly increased from 0.609147 to 2.358193 which is in the zone of non autocorrelation problem.

In the GLS estimation estimation of the western region, the independent variables of lnRURBS*, lnRIND* have a positive coefficient and statistically significant at $1 \%$ level. While, the independent variable of $\operatorname{lnRINV} *$ also showed statistically significant with a negative sign. The other two independent variables LnRFDI*, USLQ*did not pass the t-test, which means they were not statistically significant in the GLS estimation. The GLS estimation is reasonably fit as indicated by the Adjusted- $\mathrm{R}^{2}$ of 0.880199 , meaning that about 88 percent of the variation in regional GDP of central region can be explained by the variation in the dependent variables. As for the D.W. statistic, it has been greatly increased from 0.797203 to 2.315435 which is in the zone of non autocorrelation problem.

\section{Conclusion}

Based on results of the GLS estimation of the random effect panel data model, it can be concluded that the growth of urban services performed rather well in promoting regional economic growth of all of the three regions in China. The elasticity coefficients of urban services on regional growth in the eastern, central and western regions were 0.51 .0 .48 and 0.37 respectively and they were all significant at $1 \%$. But the promoting role of urban services on regional economic growth in this three regions were different among which, the role of urban services in eastern region were strongest, followed by central region and weakest in Western region. Moreover, the role of industrialization on regional economic growth in the three regions were significant. The elasticity coefficients of industrialization on regional growth in the eastern ,central and western regions were $0.49,0.48$ and 0.50 respectively showing that, so far, the secondary industry was still an important force to promote regional economic growth in China.

\section{Acknowledgments}

In completing this paper, I would like to express my deepest appreciation to my supervisor Professor Dr. ABDUL Razak bin Chik, who has been very patient in guiding me and supporting from the very beginning of my thesis. He assisted me immensely in focusing my thinking and ideas towards the right direction and gave me his valuable ideas, insights, comments and suggestions towards understanding the empirical predicaments I have encountered.

\section{REFERENCES}

[1] Barro, R. J. Macroeconomics 4th. New York: John Wiley \& Sons., 1990.

[2] Baumol ,W.J. Macroeconomics of Unbalanced Growth: the Anatomy of Urban Crsis. American EconomicReview, vol. 57, 1967, pp.415-426..

[3] Browning. H.\& Singelmann. J.The Emergence of a Service Society: Demographic and Sociological Aspects of 
the Sectoral Transformation of the Labor Force in the USA, Springfield, VA: National Technical Information Service, 1975.

[4] Chenery, H.B., Elkstein, H., \&Sims, C. A Uniform Analysis of Development Patterns. Harvard University Center for International Affairs, Economic Development Report, 148,1986 .
[5] Clark. C., The Conditions of Economic Progress,London: MacMillan Co. Ltd., 1940.

[6] Dazhong, Cheng, The Regional And Sector Characteristics of Services Growth in China. Economic Problems,vol.8.,2003.

[7] Daniels ,P. W. \& Moulaert, F., The Changing Geography of Advanced Producer Services: 